\title{
Relacje rodzice - szkoła w świetle regulacji prawnych oraz założeń systemu oświaty
}

\section{Rola relacji rodzice - szkoła}

Charakter współczesnego procesu edukacji jest kształtowany przez zróżnicowane źródła oddziaływań, m.in. różnego rodzaju media, a także szeroki wpływ ogółu społeczeństwa. Równie ważny (chociaż kwestią dyskusyjną pozostaje, czy wciąż najważniejszy) jest wpływ dwóch nakładających się na siebie i pozostających we wzajemnej interakcji systemów: rodzinnego i szkolnego. Pomimo ich powiązań, środowiska te posiadają swoją specyfikę, wpływając na wychowanka często poprzez inne, nie zawsze kompatybilne sposoby ${ }^{1}$. W perspektywie systemowej proces wychowania w obu tych środowiskach jest realizowany przez dwie zasadnicze podgrupy pozo-

${ }^{1}$ Por. E. Osewska, Wspólnota rodzinna w stużbie wychowania, „Family Forum”, 2014, nr 4, s. 125-139. T. Rostowska, Wychowawcza rola szkoły w perspektywie psychologicznej, w: Wokół wychowania: rola rodziny i szkoły w procesie socjalizacji dziecka, red. Teresa Rostowska i in., Łódź 2006, s. 47. Tradycyjnie to właśnie rodzinie i szkole przyznawano zasadniczą rolę w procesie edukacyjnym i szerzej wychowawczym, jednak od pewnego czasu, na fali m.in. rozwoju nowych mediów i kolejnych trendów w obszarze obyczajów czy zachowań społecznych, mówi się o zwiększającym się znaczeniu oddziaływań pochodzących z tych 
stające między sobą w stosunku hierarchicznym. W szkole są to nauczyciele i uczniowie, natomiast w rodzinie - rodzice i dzieci. W środowisku szkolnym przebieg edukacji i jej skuteczność są zależne od takich czynników, jak klimat emocjonalny panujący w grupie, poczucie bezpieczeństwa, a także poziom akceptacji i zrozumienia oraz typ relacji zachodzących między podmiotami. Oczywiście wśród tych czynników istotne są stawiane uczniom wymagania. Wymienione czynniki w dużym stopniu zależą od cech osobowości nauczyciela, a także - analogicznie - od cech ucznia oraz grupy rówieśniczej².

Praktyka edukacyjna pokazuje także, że na skuteczność procesu edukacyjnego duży wpływ ma powiązanie szkoły z bliskimi uczniom zdarzeniami społecznymi, dlatego szkoła nie powinna być miejscem oderwanym od naturalnej codzienności wychowanków. Siłą rzeczy ostatni z wymienionych postulatów dotyczący funkcjonowania szkoły wskazuje na wagę relacji z rodzinami uczniów, które kreują naturalne miejsce funkcjonowania społecznego dzieci. W tym aspekcie nie można pomijać także faktu potwierdzonego przez liczne badania, że poziom edukacyjnych możliwości dzieci oraz ich planów edukacyjnych, pozostaje nadal pod dużym wpływem społecznego statusu rodziny ${ }^{3}$.

Przebieg procesu edukacyjnego zasadniczo realizowanego w szkole (w odróżnieniu od procesu wychowawczego, który ma znacznie szerszy zakres) jest w takiej perspektywie nie tylko zależny od szkolnych uwarunkowań, ale także od kontekstu rodzinnego. Już to, z jakiej rodziny pochodzi dziecko, może w dużym stopniu determinować wiele jego cech i możliwości. Jak najszersze poznanie tych uwarunkowań bez bliższych relacji między obu podmiotami - rodziną i szkołą - wydaje się właściwie niemożliwe. Tymczasem tylko ich znajomość, zrozumienie i oddziaływanie na nie stanowić może podstawę dla lepszego rozwoju dziecka, będącego przecież w centrum zainteresowania wszelkiej aktywności edukacyjnej zarówno rodziny, jak i szkoły. Partnerskie relacje zachodzące wewnątrz procesu edu-

źródeł, w tym także od grup rówieśniczych kontaktujących się zresztą obecnie głównie tą drogą, szczególnie za pośrednictwem tzw. mediów społecznych (ang. Social Media).

${ }_{2}^{2}$ T. Rostowska, Wychowawcza rola szkoły..., s. 50.

${ }^{3}$ Por. J. Domalewski, P. Mickiewicz, Młodzież w zreformowanym systemie szkolnym, Toruń-Warszawa 2004, s. 92. 
kacji przynoszą więc korzyści nie tylko wychowankom, ale także rodzicom i nauczycielom ${ }^{4}$.

Analizowany tu typ relacji zdaje się od pewnego czasu przykuwać coraz więcej uwagi teoretyków i praktyków procesu edukacyjnego na całym świecie. Także w naszym kraju znaczna część refleksji nauk pedagogicznych oraz gremiów decydujących o kształcie sytemu edukacji w Polsce podkreśla znaczenie roli rodziców w procesie edukacyjnym swoich dzieci, realizowanym w warunkach kształcenia i wychowania instytucjonalnego. Tym samym wskazuje się na wagę relacji zachodzących między szkołą a rodzicami. Znajduje to swoje odbicie w szczegółowych uprawnieniach przypisywanych przez państwo rodzicom, które mają im dać możliwość oddziaływania na pracę szkoły. Ważny jest także społeczny klimat sprzyjający pobudzaniu rodzicielskiej aktywności, na bazie którego zachęca się do podejmowania różnego rodzaju inicjatyw w tym zakresie. Przejawem tej atmosfery są na przykład stowarzyszenia rodziców, których jednym z głównych celów jest wsparcie szkół czy towarzyszenie placówkom oświatowym w procesie edukacyjnym ${ }^{5}$.

\section{Prawa i obowiązki dyrektora i nauczycieli wobec rodziców}

Wszelka współpraca między rodzicami a szkołą powinna brać pod uwagę ramy wyznaczane przez obowiązki szkoły wobec rodziny, a także rodziców wobec szkoły. W przypadku szkoły obowiązki te są dzielone na: wytyczne dla szkół, obowiązki dyrektorów oraz obowiązki nałożone na nauczycieli ${ }^{6}$.

\footnotetext{
${ }^{4}$ Por. M. Mendel, Edukacja społeczna. Partnerstwo rodziny, szkoły i gminy w perspektywie amerykańskiej, Toruń 2001, s. 85. Nie chodzi tylko o edukację świecką. Nie można pomijać faktu, że w wielu przypadkach rodzina staje się także ośrodkiem wychowania religijnego pod postacią na przykład katechezy rodzinnej. E. Osewska, Praktyka katechezy rodzinnej na świecie, „Seminare” (1999), nr 15. Tej tematyce poświęcona jest także publikacja E. Osewskiej: Polska rodzina jako środowisko wychowania religijnego, w: Rodzina w trosce o życie - Kościót $w$ trosce o rodzine, red. R. Buchta, „Studia i Materiały Wydziału Teologicznego Uniwersytetu Śląskiego w Katowicach", nr 56, 2010, s. 60-69.

${ }^{5}$ Por. A. Koper, I. Kierzkowska-Żuk, Udział rodziców w życiu szkoły, „Studia i Prace Pedagogiczne”, 2016 (3), s. 108.

${ }^{6}$ Por. M. Banasiak, Wspólpraca rodziców..., s. 21.
} 
W odniesieniu do obowiązków dyrektora wobec rodziców zapisy prawne oraz ogólne wytyczne dla szkół zakładają, że ma on m.in. obowiązek: ${ }^{7}$

- informować rodziców o wszystkim, co dzieje się w szkole,

- wspomagać wychowawczo rozwój dziecka i zapewniać mu właściwą w tym celu edukację, b, a także chronić przed zagrożeniami,

- włączać rodziców w planowane działania organizacyjne (tworzenie planów, programów, wycieczki itp.).

Dyrektor szkoły powinien także przedkładać do zaopiniowania radzie szkoły (jeśli funkcjonuje w danej szkole), a następnie do zatwierdzenia radzie pedagogicznej, projekty planów pracy szkoły, kierować ich realizacją, składać radzie pedagogicznej okresowe sprawozdania $\mathrm{z}$ ich realizacji oraz udzielać informacji o działalności dydaktyczno wychowawczej szkoły radzie rodziców i radzie szkoły ${ }^{8}$.

Wymienione obszary aktywności dyrektora w jego relacjach z rodzicami mają służyć dostosowaniu podejmowanych przez szkołę działań do potrzeb, oczekiwań i działań wychowawczych rodziców. Dlatego wytyczne dotyczące roli dyrektora w szkole nie ograniczają się do jego funkcji kierowniczej, ale podkreślają, że dyrektor szkoły w wykonywaniu swoich zadań powinien współpracować z organami przedstawicielskimi działającymi na terenie szkoły, czyli z radą rodziców, radą pedagogiczną, rodzicami i samorządem uczniowskim ${ }^{9}$. Jednym z narzędzi do realizacji tak określonych celów jest stosowanie diagnozy i oceny szkolnego środowiska wychowawczego, m.in. poprzez badania oczekiwań rodziców i uczniów wobec szkoły, obejmujące także ich zainteresowania i potrzeby. Diagnoza prowadzona przez dyrektora szkoły w ramach sprawowanego przez niego nadzoru pedagogicznego odbywa się na ogół przy użyciu kwestionariusza i ankiety ${ }^{10}$.

Jeśli chodzi o obowiązki nauczycieli wobec rodziców, to za punkt wyjścia w tej kwestii należy uznać założenie, że nauczyciele w swojej pracy wychowawczej powinni wspierać w tym zakresie obowiązki rodziców ${ }^{11}$. Pro-

\footnotetext{
${ }^{7}$ M. Banasiak, Współpraca rodziców..., s. 26-27; Ministerstwo Edukacji Narodowej do dyrektorów szkół, MEN, Warszawa 1999, s. 45-46.

${ }^{8}$ Rozporządzenie Ministra Edukacji Narodowej z dnia 8 kwietnia 1997 roku w sprawie zadań nauczycieli, którym powierzono stanowiska kierownicze w szkole.

9 Tamże.

10 Ministerstwo Edukacji Narodowej o programie wychowawczym szkoły, MEN, Warszawa 2001, s. 25-27.

${ }^{11}$ Ministerstwo Edukacji Narodowej o reformie programowej, kształcenie zintegrowane, MEN, Warszawa 1999. Ustawa o systemie oświaty z dnia 7 września 1991 r. (tekst jednolity: Dz.U. z 1996 r. Nr 67, poz. 329, z późn. zm.), rozdz. 1, art. 1, pkt 2.
} 
ces wychowawczy przewiduje więc dla nauczycieli rolę uzupełniającą, przy czym ich udział $\mathrm{w}$ tym procesie musi się odbywać $\mathrm{w}$ zgodzie $\mathrm{z}$ poszanowaniem praw i obowiązków każdego obywatela. Wytyczne co do doskonalenia zawodowego nauczycieli zwracają uwagę na objęcie nim m.in. aktywnych metod prowadzenia spotkań z rodzicami oraz zdobycie przez nich wiedzy z zakresu komunikacji niewerbalnej, pomocnej w budowaniu pozytywnych relacji z innymi. Wśród obowiązków nauczycieli wymienia się także kształtowanie właściwych postaw rodziców wobec aktywizacji i rozwoju uzdolnień dzieci. Nauczyciele razem z pedagogiem i psychologiem powinni uświadamiać rodzicom prawidłowości rozwojowe dzieci oraz wskazywać sposoby stymulacji rozwojowej dziecka w rodzinie, a także udzielać wsparcia przy przekraczaniu przez dzieci kolejnych progów rozwojowych ${ }^{12}$. Nauczyciel powinien także prowadzić rzetelną ocenę postępów w nauce ucznia i informować o nich uczniów i rodziców, podobnie jak w kwestii formułowania wymagań edukacyjnych. Obowiązki nauczycieli w sferze oceniania dotyczą także pełnej jawności ocen oraz ich uzasadnienia. Analogiczne obowiązki nauczycieli dotyczą poinformowania uczniów i rodziców o proponowanej ocenie semestralnej z przedmiotu ${ }^{13}$.

Podsumowując zagadnienie praw i obowiązków nauczycieli wobec rodziców, ich najważniejsze aspekty dotyczą następujących kwestii ${ }^{14}$ :

- wspierania rodziców w pracy wychowawczej,

- prowadzenia spotkań z rodzicami,

- organizowania pogadanek, szkoleń dla rodziców,

- informowania rodziców o mocnych i słabych stronach ucznia,

- ustawicznego rozwijania swojej wiedzy i umiejętności na temat komunikacji międzyludzkiej,

- angażowania rodziców w pracę szkoły - organizowanie wycieczek, świąt, gazetek szkolnych itp.,

- utrzymywania stałego kontaktu z rodzicami,

- informowania rodziców o wynikach dzieci w nauce,

- otwartości na propozycje rodziców.

Nauczyciele pełniący rolę wychowawcy, aby optymalnie wykonywać swoje zadania, powinni otaczać indywidualną opieką każdego ze swoich

\footnotetext{
${ }^{12}$ Ministerstwo Edukacji Narodowej o dysleksji, czyli specyficznych trudnościach w nauce, MEN, Warszawa 1999, s. 12-13.

${ }^{13}$ Ministerstwo Edukacji Narodowej o ocenianiu, MEN, Warszawa 1999, s. 7-12.

${ }^{14}$ Por. M. Banasiak, Wspólpraca rodziców..., s. 29.
} 
wychowanków, razem z nimi oraz ich rodzicami planować i organizować różne formy życia zespołowego. Utrzymywanie z ich strony kontaktu z rodzicami uczniów powinno służyć poznaniu wychowanków oraz ustaleniu ich potrzeb opiekuńczo-wychowawczych, a także włączeniu ich jako wychowawców w sprawy życia klasy i szkoły. Reasumując, zgodnie z aktualnymi założeniami uznaje się, że nauczyciele z racji posiadanych kompetencji i doświadczenia powinni pełnić kluczową rolę w podtrzymywaniu kontaktów z rodziną ucznia, dbając przy tym o ścisłe współdziałanie i rozwijanie współpracy z jego środowiskiem rodzinnym ${ }^{15}$.

Analogicznie jak nauczyciele, uczniowie i dyrektorzy szkół, także rodzice mają swoje prawa i obowiązki względem szkoły. Część z nich wynika w sposób bezpośredni z zapisów przede wszystkim ustawy o systemie oświaty, część natomiast jest efektem ustaleń zawartych w statucie danej szkoły, kolejna część wynika pośrednio z praw nauczycieli, uczniów i dyrektorów w szkole. Prawa rodziców w szkole obejmują m.in. prawo do ${ }^{16}$ : rzetelnej informacji o postępach w nauce, sukcesach i problemach swoich dzieci, wypowiadania się i wyrażania uwag o pracy szkoły i jej jakości, zapoznania się z podstawowymi dokumentami szkoły (programem wychowawczo-profilaktycznym, statutem szkoły), podjęcia decyzji o udziale dziecka w zajęciach religii, poradnictwa pedagoga i wychowawcy, bezpłatnego dożywiania, decydowania o udziale dziecka w zajęciach pozalekcyjnych i zawodach sportowych, udziału w życiu szkoły (imprezy klasowe, szkolne, wycieczki, zabawy szkolne itp.), opiniowania pracy nauczycieli ubiegających się o awans zawodowy, posiadania dwóch przedstawicieli w komisji konkursowej na stanowisko dyrektora szkoły oraz udziału w radzie rodziców etc.

Obowiązki rodziców wobec szkoły są zazwyczaj dzielone na dwie zasadnicze kategorie: obowiązki wychowawcze i edukacyjne. W ramach obowiązków z pierwszej grupy wymienia się m.in.: świadomy wybór placówki, przy uwzględnieniu kryterium poziomu nauczania i programu wychowawczego, zaznajomienie się z programem wychowawczo-profilaktycznym szkoły, a także aktywne uczestnictwo $\mathrm{w}$ jego tworzeniu, rozmowa $\mathrm{z}$ nauczycielem na temat dziecka, jego trudności i zdolności, powinność zgłaszania problemów wychowawczych i prośba o pomoc w ich rozwiązaniu (nauczyciela, pedagoga i psychologa szkolnego), udział w radzie rodziców lub radzie

${ }^{15}$ Por. M. Parlak, Współpraca przedszkola z rodzicami i środowiskiem lokalnym, w: Wybrane zagadnienia z pedagogiki przedszkolnej, red. E. Zyzik, Kielce 2009, s. 178-179.

${ }^{16}$ Por. M. Banasiak, Współpraca rodziców..., s. 30. 
pedagogicznej, aktywna pomoc nauczycielowi w przygotowywaniu imprez pozalekcyjnych itp., co ma kształtować pozytywne nastawienie ucznia wobec szkoły, a także uczestnictwo w oferowanych przez szkołę kursach, szkoleniach i warsztatach dla rodziców itp. Co ważniejsze, wśród obowiązków rodziców wobec szkoły podkreśla się także ich powinność osobistego włączenia się w życie szkoły, do której uczęszcza dziecko, i bycie istotną częścią społeczności lokalnej, oraz zaangażowanie się, jako partnera, w nauczanie dzieci w szkole ${ }^{17}$.

Obowiązki rodziców zaliczane do drugiej kategorii dotyczą: zapewnienia dziecku realizacji obowiązku szkolnego oraz odpowiednich warunków do nauki w domu, poznanie programu, zgodnie $\mathrm{z}$ którym prowadzone będą zajęcia $\mathrm{w}$ szkole $\mathrm{z}$ danego przedmiotu, kontakt $\mathrm{z}$ nauczycielem i kontrolowanie wyników w nauce dziecka, motywowanie dziecka do nauki oraz branie udziału w zajęciach pozalekcyjnych, sprawdzanie zadań domowych, udzielanie wsparcia dziecku $w$ trudnościach $w$ nauce m.in. poprzez kontakt z nauczycielem, organizowanie dodatkowych zajęć wyrównawczych lub w miarę możliwości pomoc dziecku w domu, a także informowanie nauczyciela o tym, że dziecko ma trudności z nauką danego przedmiotu ${ }^{18}$.

\section{Udział rodziców w życiu szkoły według polskich regulacji prawnych}

W jednym z najbardziej podstawowych dla polskiego systemu oświaty aktów prawnych: Ustawie o systemie oświaty z 7 września 1991 roku, rola rodziców dla tego systemu została wskazana przede wszystkim poprzez podkreślenie znaczenia wychowania rodzinnego, wobec którego szkole wyznaczono głównie funkcję wspomagającą. W tym aspekcie mówi się, że wychowanie odbywa się głównie w rodzinie, a szkoła wspomaga jedynie wychowawczą rolę rodziny ${ }^{19}$.

17 Ustawa z dnia 25 lipca 2008 r. o zmianie ustawy o systemie oświaty, Ustawa - Karta Nauczyciela oraz Ustawa o postępowaniu w sprawach nieletnich (Dz.U. z dnia 8 sierpnia 2008 r.).

${ }^{18}$ Por. M. Banasiak, Współpraca rodziców..., s. 33.

${ }^{19}$ Ustawa o systemie oświaty z 7 września 1991 r. (Dz.U. 1991 nr 95 poz. 425). Taka wymowa przywołanych zapisów nie powinna specjalnie dziwić, jeśli się uwzględni, że ich bezpośrednim kontekstem były nowe doświadczenia Polskiej Rzeczypospolitej Ludowej, 
Takie ujęcie wychowania w szkole wskazuje, że i w tej sferze, jeśli nie zasadnicza, to bardzo ważna rola powinna przypaść rodzicom. A jak wygląda to w praktyce? W szeroko pojętym prawodawstwie dotyczącym systemu oświaty w Polsce funkcjonuje szereg zapisów odnoszących się do roli rodziców w tym systemie, także z uwzględnieniem bezpośrednio z tym związanej kwestii relacji między rodzicami a szkołą. Zainteresowanie znaczeniem rodziców dla funkcjonowania polskiego systemu oświatowego wzrosło szczególnie w drugiej połowie lat 90 . XX wieku, w okresie prac nad reformą systemu oświatowego, oraz w trakcie jej wprowadzenia w życie, czyli od 1999 roku. Nowe zasady systemu szkolnego zostały wprowadzone zapisami ustawy oświatowej uchwalonej przez sejm 25 lipca 1998 roku. Jedną z najbardziej znaczących cech tej reformy była jej kompleksowość. Wynikała ona z jednoczesnego wprowadzenia zmiany ustroju szkolnego, nowych zasad zarządzania i finansowania placówek oświatowych, reformy programów wraz z nowym systemem egzaminacyjnym, zmian w statusie nauczycieli, a także nowego podejścia do formułowania zasad funkcjonowania szkół ${ }^{20}$. Kolejne elementy reformy były wprowadzane stopniowo od 1999 roku. Od samego początku prac nad reformą za jeden z jej głównych celów uznano wzmocnienie pozycji rodziców $\mathrm{w}$ sprawach swoich dzieci oraz uczynienie $\mathrm{z}$ nich równorzędnych partnerów dla samorządów i dyrektorów szkół. Takie ukierunkowanie reformy potwierdziła nowelizacja ustawy o systemie oświaty i innych ustaw dokonana ustawą z dnia 11 kwietnia 2007 roku $^{21}$. Także ta zmiana była uzasadniana dążeniem do podniesienia rangi rodziców i zwiększenia ich roli w funkcjonowaniu szkoły. Tak duże znaczenie kwestii podniesienia statusu rodziców $w$ reformowanym systemie oświaty wynikało m.in. z głównych założeń reformy, które zakładały spójność działań wychowawczych pomiędzy szkołą i rodziną 22 . W tym duchu, analogicznie jak

czyli rodzimej odmiany realnego socjalizmu, z typowymi dla niego staraniami o wchłonięcie wszelkich przejawów życia społecznego, w tym także związanych z procesem wychowawczym. Nawet jeśli polska wersja tego systemu miała być względnie łagodniejsza (m.in. za sprawą wciąż wielkiej roli Kościoła Katolickiego i jego nauczania o nastawieniu personalistycznym) niż w sąsiednich "demoludach", to jednak podstawowe założenia stojące za tym systemem o totalistycznym charakterze wszędzie były analogiczne.

${ }^{20}$ Ustawa z dnia 25 lipca 1998 r. o zmianie ustawy o systemie oświaty (Dz.U. 1998, $\mathrm{nr} 117$, poz.759; $\mathrm{nr} 162$, poz. 1126).

${ }^{21}$ Ustawa z dnia 11 kwietnia 2007 r. o zmianie ustawy o systemie oświaty oraz o zmianie niektórych innych ustaw (Dz.U. z 2007r. Nr 80, poz. 542).

${ }_{22}$ Ministerstwo Edukacji Narodowej o wychowaniu w szkole, MEN, Warszawa 1999, s. 10. 
we wspomnianym podejściu prezentowanym w Ustawie o systemie oświaty z 7 września 1991 roku, podkreślana była konieczność uzupełniania przez szkołę wychowawczej roli rodziny. Na tej podstawie przyjmuje się m.in., że rodzice uczniów, jeszcze przed podjęciem nauki przez dziecko w danej placówce, powinni zostać poinformowani o kodeksie wymagań edukacyjnych i wychowawczych, jakie stawia szkoła, za pośrednictwem szkolnego programu wychowawczego ${ }^{23}$.

Rodzice, w myśl założeń prezentowanej reformy oświaty, są uznawani za pierwszych wychowawców, z czego wynika ich prawo do decydowania o całym procesie wychowania dziecka, także o tej jego części, która ma miejsce w szkole, co uprawnia ich do poznania programu wychowawczego szkoły i wpływania na jego kształt ${ }^{24}$. Szkoła powinna także informować rodziców o wszelkich zmianach zachodzących w placówce. W myśl założeń reformy systemu oświatowego realizowanej od 1999 roku szkoła powinna się stać szkołą podmiotową, która na pierwszym miejscu stawia rozwój ucznia. W związku ze wspomnianym ujęciem roli rodziców jako pierwszego wychowawcy uznano, że także w okresie nauki szkolnej dzieci, gdy rodzice nadal odgrywają istotną rolę w kształtowaniu ich osobowości, niezbędne jest przybliżenie im problematyki kolejnych etapów rozwoju dzieci i ich specyficznych potrzeb na każdym z nich. Za sprawą takich działań praca wychowawcza nauczycieli w szkole i rodziców w domu uzupełniałaby się, a nie wykluczała. Uzupełniająca rola szkoły w procesie wychowawczym, w myśl założeń omawianej reformy miałaby także polegać na wsparciu rodziny w przekazywaniu dorobku kulturalnego i uzupełnianiu wiedzy przekazywanej przez rodzinę w tym zakresie $\mathrm{e}^{25}$.

Z punktu prawno-formalnego szczególna waga została przypisana w tym obszarze radom rodziców, które powinny pełnić rolę ich reprezentacji.

Szczegółowe kompetencje rady rodziców obejmują m.in.:

- wyrażanie opinii w sprawie zestawu programów wychowania przedszkolnego lub szkolnego zestawu programów nauczania i szkolnego zestawu podręczników ${ }^{26}$;

\footnotetext{
23 Tamże, s. 6-7.

${ }^{24}$ Ministerstwo Edukacji Narodowej o programie wychowawczym szkoły, MEN, Warszawa 2001.

${ }^{25}$ Por. M. Banasiak, Wspótpraca rodziców..., s. 21.

${ }^{26}$ Ustawa z dnia 7 września 1991 r. o systemie oświaty i jej nowelizacja z dnia 11 kwietnia 2007 r., art. 22 a ust. 2 b.
} 
- wnioskowanie zmian w zestawie programów wychowania przedszkolnego lub szkolnym zestawie programów nauczania, a także szkolnym zestawie podręczników ${ }^{27}$;

- udział przedstawicieli rodziców w komisji konkursowej powołanej w celu wyboru dyrektora ${ }^{28}$;

- opiniowanie podjęcia i prowadzenia w szkole działalności przez stowarzyszenia i inne organizacje ${ }^{29}$;

- kompetencje rady rodziców ${ }^{30}$.

W kwestiach dotyczących pracy nauczycieli rady rodziców są m.in. uprawnione do wnioskowania o ocenę pracy nauczyciela ${ }^{31}$ oraz do przedstawienia swojej opinii na temat oceny dorobku zawodowego nauczyciela stażysty, kontraktowego i mianowanego za okres stażu ${ }^{32}$. Kolejne regulacje, przede wszystkim Ustawa z dnia 11 kwietnia 2007 r. o zmianie ustawy o systemie oświaty (i następne nowelizacje), szły w kierunku dalszego zwiększenia kompetencji rad rodziców w szkołach publicznych prowadzonych przez organ władzy publicznej. Zapisy znowelizowanej ustawy o systemie oświaty wprowadzily także obligatoryjność funkcjonowania rady rodziców w szkołach i placówkach publicznych. W świetle wcześniejszych regulacji (w ustawie o systemie oświaty z dnia 7 września 1991 roku) istniała tylko możliwość tworzenia takich rad, a nie był to obowiązek. Nowe zapisy, oprócz obligatoryjności powołania rad rodziców, wprowadziły również obowiązek powoływania rady rodziców w każdym roku szkolnym na nowo. W skład rady rodziców zgodnie z prezentowanymi regulacjami mają wchodzić reprezentanci rodziców uczniów z wszystkich klas. Jednym z zasadniczych zadań rady jest formalne uchwalanie w porozumieniu z radą pedagogiczną programu wychowawczo-profilaktycznego szkoły i programu profilaktyki ${ }^{33}$.

Zgodnie z omawianymi zapisami wśród zadań rady rodziców znalazło się także opiniowanie projektu planu finansowego składanego przez dyrektora szkoły. Innym ważnym uprawnieniem tego organu przedstawiciel-

\footnotetext{
${ }^{27}$ Tamże, art. 22a ust. 2 g.

${ }^{28}$ Tamże, art. 36 a ust. 5 pkt 2 b oraz ust. 5 b pkt 2 .

${ }^{29}$ Tamże, art. 56 ust. 2.

${ }^{30}$ Tamże, art. 54.

${ }^{31}$ Ustawa z dnia 26 stycznia 1982 r. Karta Nauczyciela z późniejszymi zmianami, art. 6a ust. 1 pkt. 5 .

${ }^{32}$ Tamże, art. 9c ust. 6 pkt. 1 i 2.

33 Ustawa z dnia 14 grudnia 2016 r. Prawo oświatowe, art. 84 (Dz.U. z 2018 r. poz. 996, 1000 i 1290).
} 
skiego stała się możliwość jego wpływu na decyzje dotyczące działalności stowarzyszeń i organizacji społecznych na terenie szkoły. Bardzo istotnym uprawnieniem przyznanym radom rodziców jest także tworzenie wspólnie z nauczycielem, dyrektorem oraz radą pedagogiczną programu nauczania w danej szkole ${ }^{34}$. Do wspólnych zadań rady rodziców i rady pedagogicznej należy także opracowanie szczegółowych celów kształcenia i wychowania ${ }^{35}$. W świetle przywołanych zapisów rady rodziców uzyskały także prawo występowania do organu prowadzącego szkołę lub placówkę, organu sprawującego nadzór pedagogiczny, dyrektora, rady pedagogicznej oraz rady szkoły lub placówki z wnioskami i opiniami dotyczącymi wszystkich spraw szkoły lub placówki ${ }^{36}$.

Podsumowując problematykę roli i statusu rodziców w dobie całościowej reformy polskiego systemu oświaty zapoczątkowanej w 1999 roku, można stwierdzić, że w aktach prawnych dotyczących tej reformy znalazło się wiele wytycznych dla dyrektorów szkół i nauczycieli o obowiązkach względem rodziców. Można także wskazać, że w warstwie formalno-prawnej zreformowany system edukacji zakłada dużą aktywność rodziców w szkole. Zgodnie z tymi założeniami rodzice uzyskali pełne prawo do współdecydowania o niemal wszystkich aspektach edukacji ich dziecka. W myśl regulacji przyjmowanych w trakcie reformy systemu oświaty podkreślona została potrzeba utrzymywania pozytywnych, partnerskich relacji rodziców i nauczycieli. Propagowanie takiego podejścia ma służyć podniesieniu jakości edukacji, poprawieniu wyników dzieci w nauce oraz wyrobieniu w uczniach pozytywnej postawy wobec szkoły. Taka waga przypisana relacji szkoły z rodziną w ramach reformowania systemu oświaty wynikała $z$ negatywnej oceny pracy wychowawczej szkoły w okresie poprzedzającym wprowadzenie reformy (czyli de facto $\mathrm{w}$ trakcie pierwszej dekady funkcjonowania polskiej szkoły po rozpoczęciu w 1989 roku transformacji ustrojowej). Za jedną

\footnotetext{
${ }^{34}$ Ministerstwo Edukacji Narodowej o programach nauczania, gimnazjum, MEN, Warszawa 1999, s. 4. Ustawa o systemie oświaty z dnia 7 września 1991 roku rozdz. 4, art. 53.1, art. 53.2, art. 53.3, art. 53.4.

${ }^{35}$ Ustawa $\mathrm{z}$ dnia 5 listopada 2009 r. zmieniająca ustawę o systemie oświaty oraz ustawę o zmianie ustawy o systemie oświaty oraz o zmianie niektórych innych ustaw (Dz.U. z dnia 22 grudnia 2009 r.). Ustawa z 7 września 1991 roku o systemie oświaty, rozdz. 4, art. 54.1, Ustawa z dnia 7 września 1991 r. o systemie oświaty, rozdz. 3, art. 22.2, ust. 4.d.

${ }^{36}$ Ustawa $\mathrm{z}$ dnia 5 listopada 2009 r. zmieniająca ustawę o systemie oświaty oraz ustawę o zmianie ustawy o systemie oświaty oraz o zmianie niektórych innych ustaw (Dz.U. z dnia 22 grudnia 2009 r.). Ustawa o systemie oświaty z dnia 7 września 1991 roku, rozdz. 4, art. 54.1.
} 
z głównych przyczyn niepowodzeń polskiej szkoły w sferze wychowawczej w tym okresie uznano właśnie brak współpracy szkoły i domu rodzinnego. To dlatego jednym z głównych celów podjętych w trakcie reformy działań było wprowadzenie takich regulacji, które w kontekście współpracy ze środowiskiem rodzinnym służyłyby do odtworzenia naturalnej odpowiedzialności za los dziecka, którą powinny ponosić osoby mu najbliższe ${ }^{37}$.

Praktyka funkcjonowania szkół pokazuje jednak, że realizacja zapisów prawnych w rzeczywistych warunkach nie zawsze prowadzi do osiągnięcia wszystkich celów, które zostały im przypisane. Znamiennym przykładem takich rozbieżności między teoretycznymi założeniami a ich praktyczną realizacją są różne aspekty rzeczywistej działalności tak eksponowanego od czasów reformy systemu oświaty organu, jakim w świetle nowych przepisów stały się rady rodziców.

Jeśli chodzi na przykład o ich udział w uchwaleniu programu wychowawczo-profilaktycznego, to zazwyczaj jest to czynność tylko formalna, ponieważ faktyczne planowanie oddziaływań w tym zakresie należy do nauczycieli. W ramach tak ukształtowanej praktyki edukacyjnej zakres aktywności rady rodziców sprowadza się w zasadzie do służebnej roli, która stoi w wyraźnej opozycji do wizji szkoły jako podmiotu aktywizującego nie tylko kadrę pedagogiczną, ale także rodziny uczniów. Sam przepis odnoszący się do tej kwestii nie narzuca instrumentalnego traktowania rodziców, wprost przeciwnie, $u$ jego podstaw tkwi raczej założenie, iż proces uchwalania wspomnianych programów będzie miał charakter w pełni świadomy, opierając się na debacie wewnątrzszkolnej oraz diagnozie identyfikującej potrzeby w zakresie pracy wychowawczej i profilaktyki ${ }^{38}$.

Doświadczenia w realizacji innych zapisów obejmujących uprawnienia zarówno indywidualne, jak i zbiorowe rodziców także wskazują na raczej niejednoznaczny obraz ich faktycznej roli w polskiej szkole. I tak na przykład mimo że w ramach szczegółowych przepisów regulujących zasady oceniania i klasyfikowania uczniów przewidziane jest indywidualne prawo rodziców do informacji, a także prawo do wnioskowania (np. o wcześniejsze rozpoczęcie obowiązku szkolnego, naukę religii, naukę języka i kultury danego narodu, grupy etnicznej itp.), to ich realizacja zasadniczo zależy od rzetelności i obowiązkowości nauczycieli, od dobrej woli i możliwości eko-

\footnotetext{
${ }^{37}$ M. Kowalczyk-Szymańska, Rodzice w zreformowanej szkole, „Nowe w Szkole” (2005), nr 3.

${ }^{38}$ Por. A. Koper, I. Kierzkowska-Żuk, Udział rodziców..., s. 109.
} 
nomicznych, prawnych i organizacyjnych dyrektora szkoły. Podobna sytuacja dotyczy wpływu rodziców na decyzje organów nadzoru, na przykład w zakresie prawa rady rodziców do wnioskowania o dokonanie oceny pracy dyrektora). W praktyce szkolnej realizacja uprawnień rodziców w sferze współdecydowania najczęściej ogranicza się do współdecydowania (prawo indywidualne) razem $\mathrm{z}$ radą pedagogiczną o powtarzaniu klasy przez ucznia z oddziałów I-III (w wyjątkowych przypadkach). Zazwyczaj decyzja określająca wyjątkowość danego przypadku jest podejmowana w gronie samej rady pedagogicznej ${ }^{39}$.

Podobnie niejednoznaczna sytuacja panuje, jeśli chodzi o faktyczną rolę rodziców w sferze tych działań współczesnej polskiej szkoły, które dotyczą szeroko pojętej aktywności wspierającej, obejmującej m.in. działania opiekuńcze i organizacyjne. W tym przypadku może to być także wynikiem dość ogólnikowego charakteru odnoszących się do tej sfery regulacji zawartych w przepisach prawa oświatowego. Z jednej strony taka ich ogólna wymowa teoretycznie daje rodzicom, a ściśle rzecz biorąc ich szkolnym przedstawicielstwom dość szerokie możliwości podjęcia różnych form aktywności, mimo że nie precyzuje ich form, co może utrudniać wybór kierunków działania ${ }^{40}$.

Podstawą wszelkich działań podejmowanych przez rodziców jest przewidziana dla rady rodziców możliwość gromadzenia funduszy w celu wspierania działalności statutowej szkoły ${ }^{41}$. Uprawnienia rady rodziców $\mathrm{w}$ tym zakresie przewidują także, że to ona sama w swoim regulaminie określa zasady wydatkowania tych funduszy. Wskazana regulacja, gwarantująca swobodę decydowania przez samych rodziców o tym, na co i jak wydatkowane zostaną zebrane przez nich fundusze, zdaje się umożliwiać im osiągnięcie realnego wpływu na szkołę. Praktyka korzystania przez rady rodziców z przywołanego uprawnienia pokazuje, że zazwyczaj skupiają się one na dofinansowaniu szkoły w pomoce dydaktyczne, organizacji imprez, uroczystości, wsparciu finansowym uczniów pozostających w trudniejszej sytuacji materialnej, a więc przede wszystkim na działaniach organizacyjno-opiekuńczych ${ }^{42}$.

\footnotetext{
39 Tamże, s. 110.

40 Tamże, s. 111.

${ }^{41}$ Ustawa z dnia 7 września 1991 o systemie oświaty (Dz.U. z 2016 r. poz. 1943, z późn. zm.), art. 54

42 Por. A. Koper, I. Kierzkowska-Żuk, Udział rodziców..., s. 110.
} 
Kolejne formalne uprawnienia rodziców w warunkach współczesnej szkoły w Polsce wynikają z możliwości powoływania rady szkoły (lub placówki). Co prawda nie jest to instytucja ograniczona do rodziców (wybieranych w jej szeregi przez ogół rodziców), bowiem w jej gronie powinni się także znaleźć przedstawiciele uczniów i nauczycieli, jednak niewątpliwie jest ona organem dającym potencjalnie duże możliwości dla inicjatywy rodzicielskiej. Uprawnienia przypisane tej instytucji zdają się im (a także przedstawicielom pozostałych grup biorących udział w życiu szkoły) nadawać dość szeroką możliwość realnego oddziaływania właściwie na wszystkie najważniejsze szkolne procesy edukacyjne. Przejawia się to na przykład w uprawnieniu do uczestnictwa w rozwiązywaniu spraw wewnętrznych szkoły, wiążącym charakterze składanych wniosków o ocenę działalności szkoły, pracy dyrektora czy nauczyciela. Rada szkoły na wniosek jej członków może więc brać dość szeroki udział w ocenie panującej w danej szkole sytuacji, a także jej stanu ${ }^{43}$.

Wśród bardziej szczegółowych uprawnień rady szkoły należy także wymienić: prawo do uchwalenia statutu szkoły lub placówki, prawo do przedstawienia wniosków w sprawie rocznego planu finansowego środków specjalnych szkoły lub placówki, a także opiniowania projektu jej planu finansowego. Jak wspomniano, rada szkoły może także występować do organu sprawującego nadzór pedagogiczny nad szkołą z wnioskami o zbadanie i dokonanie oceny działalności szkoły, a także jej dyrektora czy konkretnego nauczyciela w niej zatrudnionego, przy czym wnioski te mają dla organu charakter wiążący. Do jej uprawnień należy także opiniowanie planu pracy szkoły lub placówki oraz projektów innowacji i eksperymentów pedagogicznych oraz innych spraw istotnych dla szkoły lub placówki ${ }^{44}$.

Rada szkoły na podstawie podjętej z własnej inicjatywy oceny sytuacji oraz stanu szkoły lub placówki może także wystąpić z odpowiednimi wnioskami do dyrektora, rady pedagogicznej, organu prowadzącego szkołę lub placówkę oraz do wojewódzkiej rady oświatowej, w szczególności w sprawach organizacji zajęć ${ }^{45}$. Rada szkoły jest także uprawniona do gromadzenia funduszy z dobrowolnych składek oraz innych źródeł, które mogą zo-

\footnotetext{
${ }^{43}$ Ustawa z dnia 7 września 1991 o systemie oświaty (Dz. U. z 2016 r. poz. 1943, z późn. zm.), art. 50 .

44 Tamże.

${ }^{45}$ Kwestii organizacji zajęć poświęcono art. 64 ust. 1 pkt 2. Ustawy z dnia 7 września 1991 r. o systemie oświaty.
} 
stać użyte na wspieranie działalności statutowej szkoły lub placówki. Zasady wydatkowania funduszy przez radę szkoły, podobnie jak w przypadku rad rodziców, są określane przez odrębny regulamin ${ }^{46}$.

Z punktu widzenia uprawnień formalnoprawnych rady szkoły wydają się organami przedstawicielskimi o dużym zakresie oddziaływań na życie szkoły. Praktyka funkcjonowania polskich szkół pokazuje jednak, że - jak dotąd - rady tego rodzaju należy uznać za rzadkość, a nie powszechną regułę ${ }^{47}$.

\section{Rola i status rodziców we współczesnej polskiej szkole według standardów i wymagań jakościowych}

Obok mniej lub bardziej szczegółowych przepisów prawa związanego z systemem oświaty, kwestii roli i statusu rodziców w polskiej szkole jest poświęcona także część standardów i wymagań jakościowych stawianych placówkom oświatowym. W latach 1999-2005 postulaty w tej sferze były formułowane pod postacią standardów, podczas gdy od roku 2009 przyjęły formę wymagań. W obu przypadkach, ich główny cel był analogiczny, bowiem miały one pełnić rolę wskaźników oczekiwanego przez państwo sposobu działania szkół i placówek oświatowych w różnych płaszczyznach/ obszarach ich funkcjonowania. Standardy w przeszłości, a wymagania obecnie, stanowią punkt odniesienia do opisu i oceny pracy szkół, służąc za podstawę do budowania jakości. Standardy przyjęte w latach 1999-2004 były formułowane na poziomie poszczególnych województw, będąc dowodem lokalnej, dostosowanej do specyfiki regionu, polityki oświatowej ${ }^{48}$.

W okresie od 1999 do 2005 roku rola rodziców w życiu szkoły odbywała się według dwóch standardów współpracy: wewnętrznej oraz zewnętrznej. Pierwsza koncentrowała się na kwestiach dotyczących reprezentacji rodziców, czyli przede wszystkim na radzie rodziców jako organie szkoły, postulując jej ścisłą współpracę z pozostałymi organami: dyrektorem, radą pedagogiczną, samorządem uczniowskim. Proces współpracy był w przywołanym standardzie postrzegany jako podzielony na dość wyraźne eta-

\footnotetext{
${ }^{46}$ Kwestii regulaminu dotyczy art. 51 ust. 55 Ustawy o systemie oświaty z dnia 7 września 1991 roku.

${ }^{47}$ Por. A. Koper, I. Kierzkowska-Żuk, Udział rodziców..., s. 111.

${ }^{48}$ Tamże. Warto jednak zaznaczyć, że pomimo pewnych lokalnych różnic sposób ich formułowania w poszczególnych województwach był bardzo zbliżony.
} 
py. Etap początkowy dotyczył planowania współpracy i obejmował takie działania, jak zaznajomienie się z kompetencjami organów oraz zapisami odpowiednich regulacji statutowych określających zasady współdziałania. Kolejny etap według standardu współpraca wewnętrzna miał polegać na realizacji wcześniej przyjętego planu. Ostatnim etapem w tym podejściu było uzyskanie planowanych efektów, które miały przejawiać się przede wszystkim w odpowiedzialnej realizacji kompetencji poszczególnych organów placówki, podniesieniem poziomu pracy szkoły i zadowolenia/satysfakcji uczestników współpracy. Zakres współpracy w przywołanym standardzie skupiał się w głównej mierze na udziale organów szkoły w procesie zarządzania placówką i planowaniu jej rozwoju ${ }^{49}$. Standard drugi: współpraca zewnętrzna, skupiał się natomiast na współpracy z rodzicami jako ogółem. Jej zasady określały wymagania szczegółowe: szkoła planuje współpracę $\mathrm{z}$ rodzicami; współpraca $\mathrm{z}$ rodzicami przebiega zgodnie z ustalonym planem i zasadami; szkoła w sposób celowy i zaplanowany zbiera od rodziców informacje o dzieciach; szkoła w sposób celowy i zaplanowany przekazuje rodzicom informacje o postępach i trudnościach dzieci; szkoła ustala/ konsultuje $\mathrm{z}$ rodzicami sposób pracy z dziećmi; szkoła stwarza warunki umożliwiające rodzicom aktywny udział w jej działaniach; zgłaszane przez rodziców wnioski i uwagi o działaniu szkoły są uwzględniane w pracy szkoły ${ }^{50}$. Przez kilka kolejnych lat (od 2005) standardy były już formułowane na poziomie krajowym ${ }^{51}$.

Od roku 2009 zaczęła obowiązywać nowa koncepcja nadzoru, która m.in. wprowadziła ewaluację jako jedną z głównych form sprawdzania jakości funkcjonowania szkół. Wraz z nowym podejściem do nadzoru pojawily się także tak zwane wymagania opracowane na poziomie ogólnokrajowym $^{52}$. Zgodnie $\mathrm{z}$ ich charakterem $\mathrm{w}$ wymaganiach kładzie się główny

49 Tamże, s. 112.

50 Załącznik do Rozporządzenia Ministra Edukacji Narodowej i Sportu z dnia 23 kwietnia 2004 r. w sprawie szczegółowych zasad sprawowania nadzoru pedagogicznego, wykazu stanowisk wymagających kwalifikacji pedagogicznych, kwalifikacji niezbędnych do sprawowania nadzoru pedagogicznego, a także kwalifikacji osób, którym można zlecać prowadzenie badań i opracowywanie ekspertyz (Dz.U. 2004 nr 89, poz. 845).

${ }^{51}$ Zakres i przedmiot tych standardów został określony w załączniku do Rozporządzenia Ministra Edukacji Narodowej i Sportu z dnia 23 kwietnia 2004 r. (Dz.U. 2004 nr 89, poz. 845).

52 Treść wymagań określił załącznik do Rozporządzenia Ministra Edukacji Narodowej z dnia 7 października 2009 r. w sprawie nadzoru pedagogicznego (Dz.U. 2009 nr 168 poz. 1324, z późn. zm.). Od 2015 r. stały się treścią odrębnego Rozporządzenia Ministra Edukacji 
nacisk na docelowy stan rzeczy, czyli na wizję efektów prac podejmowanych przez szkołę w ramach współpracy z rodzicami. Nazwa „wymagania”, które jest tu analizowane - rodzice są partnerami szkoły - zdecydowanie podkreśla znaczenie rodziców jako głównego podmiotu omawianej relacji. W charakterystykach wymagań na poziomie wysokim mówi się o realizacji inicjatyw rodziców na rzecz rozwoju uczniów oraz szkoły lub placówki. Na poziomie podstawowym wymaganie dotyczy następujących kwestii: szkoła lub placówka pozyskuje i wykorzystuje opinie rodziców na temat swojej pracy; w szkole lub placówce współpracuje się z rodzicami na rzecz rozwoju ich dzieci; rodzice współdecydują w sprawach szkoły lub placówki i uczestniczą w podejmowanych działaniach ${ }^{53}$.

Bardziej szczegółowe kryteria odniesione do podstawowego i wysokiego poziomu spełniania wymagania jeszcze dobitniej (niż wcześniejsze standardy) zdają się akcentować zmianę perspektywy patrzenia na partycypację rodziców w życiu szkoły, postrzegając ich jako aktywnych uczestników, realizatorów i współrealizatorów szkolnych procesów. Aktywność rodziców w życiu szkoły jest w przywołanym wymaganiu uznana za docelowy, oczekiwany stan rzeczy. Analizując przytoczone wcześniej kryteria przypisane do spełnienia podstawowego poziomu omawianego wymagania, należy zwrócić uwagę, że pomimo ich nacisku w warstwie językowej na podmiotowość rodziców, w rzeczywistości odnoszą się one do formalno-organizacyjnego, uregulowanego prawem zakresu obecności rodziców w życiu szkoły. W związku z takim ujęciem podkreślają jednocześnie powinności placówki oświatowej wobec rodziców ${ }^{54}$.

Nieco inaczej przedstawia się ta kwestia w przypadku kryteriów powiązanych $\mathrm{z}$ wysokim poziomem spełniania analizowanego wymagania. $\mathrm{W}$ ich ramach wprost kładzie się nacisk na obecność rodziców w codziennym życiu szkoły i ich wpływ na jej funkcjonowanie. Można w tym kontekście przypomnieć na przykład takie kryteria, jak: rodzice mają wpływ na życie

Narodowej z dnia 6 sierpnia 2015 r. w sprawie wymagań wobec szkół i placówek (Dz.U. 2015 poz. 1214).

${ }^{53}$ Załącznik do Rozporządzenia Ministra Edukacji Narodowej z dnia 7 października 2009 r. w sprawie nadzoru pedagogicznego (Dz.U. 2009, nr 168 poz. 1324, z późn. zm.). Rodzice są partnerami szkoły lub placówki; http://npseo.wzks.uj.edu.pl/action/requirements/ wymaganie9_rodzice_sa_partnerami_szkoly (dostęp: 27.07.2018).

${ }_{54}$ Załącznik do Rozporządzenia Ministra Edukacji Narodowej z dnia 7 października 2009 r. w sprawie nadzoru pedagogicznego (Dz.U. 2009 nr 168 poz. 1324, z późn. zm.). 
szkoły, rodzice uczestniczą w działaniach organizowanych przez szkołę ${ }^{55}$. Warto przy tym zaznaczyć, że pomimo kolejnych zmian rozporządzenia w sprawie nadzoru pedagogicznego oraz wymagań wobec szkół i placówek, opisany tu sposób postrzegania roli rodziców w zasadzie nie uległ poważniejszym zmianom ${ }^{56}$.

\section{Formy współpracy rodziców ze szkołą}

W poprzednich paragrafach zaprezentowano formalno-prawne uwarunkowania współpracy rodziców ze szkołą. Poniżej pokazano formy, w jakich ta współpraca przebiega w polskiej praktyce oświatowej. W odniesieniu do tej kwestii należy podkreślić, że punktem wyjścia do prawidłowej współpracy rodziny i szkoły jest dążenie do wspólnego dla obu podmiotów relacji celu, którym w tym przypadku jest niewątpliwie dobro dziecka. Bez dążenia do realizacji tak postrzeganego celu i w duchu tych samych wartości budowanie bardziej trwałych relacji i konstruktywne rozwiązywanie konfliktów byłoby na dłuższą metę niemożliwe ${ }^{57}$.

Formy współpracy szkoły i rodziny są klasyfikowane według różnych kryteriów. Wśród najbardziej rozpowszechnionych wskazuje się następujące postacie współpracy rodziców i szkoły: indywidualne i zbiorowe spotkania, pośrednie kontakty oraz świadczenie wzajemnych usług ${ }^{58}$. Inne spotykane w literaturze przedmiotu klasyfikacje wyróżniają zbiorowe spotkania $\mathrm{z}$ rodzicami, spotkania towarzyskie, spotkania z ekspertem, indywidualne formy współdziałania ${ }^{59}$.

${ }^{55}$ Załącznik do Rozporządzenia Ministra Edukacji Narodowej z dnia 7 października 2009 r. w sprawie nadzoru pedagogicznego (Dz.U. 2009 nr 168 poz. 1324, z późn. zm.).

${ }^{56}$ Por. A. Koper, I. Kierzkowska-Żuk, Udział rodziców..., s. 113.

57 Por. S. Rogala, Partnerstwo rodziców i nauczycieli, Warszawa-Wrocław 1989, s. 11. Swoistym wariantem takiego partnerstwa w zakresie edukacji jest na przykład współpraca rodziców w wychowaniu religijnym z wybraną instytucją szkolną. O tym szerzej na przykładzie uwarunkowań brytyjskich: E. Osewska, Edukacja religijna w szkole katolickiej w Anglii $i$ Walii ws świetle „Living and sharing our Faith. A national Project of catechesis and religious education", Tarnów 2008.

${ }^{58}$ Por. M. Łobocki, Współdziałanie rodziców i nauczycieli w procesie wychowania, Warszawa 1985, s. 225.

${ }^{59}$ Por. E. Gaweł-Luty, Optymalizacja współdziałania nauczycieli klas początkowych z rodzicami uczniów, Słupsk 1992, s. 25. 
Zbiorowe formy współpracy obejmują przede wszystkim zebrania (wywiadówki) z rodzicami, które można określić jako spotkania robocze. Uznaje się je za tradycyjne formy współdziałania szkoły i domu. W ich trakcie rodzice uzyskują informacje o postępach w nauce swoich dzieci, ich problemach, także wychowawczych, oraz ogólne wiadomości o najważniejszych sprawach klasowych. Wciąż jest to najczęstsza postać współpracy, ale jak się ocenia, nie najkorzystniejsza. W tym aspekcie podkreśla się, że nauczyciel na takim spotkaniu ma niejako uprzywilejowaną pozycję, co wręcz uniemożliwia nawiązanie relacji pomiędzy nim a rodzicami na bardziej partnerskich warunkach ${ }^{60}$. Kolejną formą kontaktu nauczyciela z rodzicami są spotkania o charakterze towarzyskim. Spotkania tego typu mają miejsce albo poza szkołą, albo w trakcie spotkań z okazji uroczystości szkolnych lub klasowych. Co istotne, w ich trakcie atmosfera jest na ogół mniej formalna, często serdeczna, co umożliwia obu stronom zdobycie się na większą otwartość, sprzyjając obustronnemu poznaniu ${ }^{61}$. Kolejna z form współpracy między rodzicami i szkołą wykracza poza kontakty z nauczycielem i polega na spotkaniach z ekspertem, które dotyczą spraw przekraczających kompetencje zawodowe i możliwości nauczyciela ${ }^{62}$. Ten typ spotkań można podzielić na dwie podkategorie: spotkania dotyczące trudności wychowawczych oraz na spotkania stawiające sobie za cel pedagogizację rodziców ${ }^{63}$. Spotkania $\mathrm{z}$ ekspertem mogą mieć różne przyczyny, jednak niemal w każdym przypadku ta postać współpracy zakłada poszerzenie wiedzy, rozwiązanie problemów lub przynajmniej zapoznanie się z kwestiami, na które powinno się zwrócić uwagę, by zapobiec potencjalnym problemom w przyszłości ${ }^{64}$.

Indywidualna postać współpracy rodziców i szkoły obejmuje zróżnicowaną grupę form relacji i kontaktu między obu podmiotami. W jej ramach można wskazać m.in. na: konsultacje pedagogiczne, wizyty domowe, kontakty korespondencyjne, rozmowy telefoniczne ${ }^{65}$. Za jedną z najważniej-

\footnotetext{
${ }^{60}$ Por. M. Mendel, Rodzice i nauczyciele jako sprzymierzeńcy, Gdańsk 2007, s. 68.

${ }^{61}$ Por. E. Gaweł-Luty, Wymiana informacji pomiędzy nauczycielem-wychowawca klasy I-III szkoły podstawowej a rodzicami uczniów, Słupsk 1995, s. 27.

62 Por. M. Łobocki, Formy współdziałania z rodzicami, w: M. Łobocki, $A B C$ wychowania dla nauczycieli i wychowawców, Warszawa 1992.

${ }^{63}$ Por. M. Banasiak, Wspótpraca rodziców ze szkoła w kontekście reformy edukacji w Polsce, Toruń 2013, s. 38; E. Gaweł-Luty, Wymiana informacji..., s. 27-28.

${ }^{64}$ E. Gaweł-Luty, Wymiana informacji..., s. 27-28.

${ }^{65}$ M. Banasiak, Wspótpraca rodziców ze szkoła w kontekście reformy edukacji w Polsce, Torun 2013, s. 39.
} 
szych indywidualnych form współpracy uznaje się konsultacje pedagogiczne. Ich znaczenie wynika $\mathrm{z}$ faktu, iż w wielu przypadkach umożliwiają one nie tylko wymianę informacji o dziecku, ale pozwalają także na wspólne ustalenie przez rodzica i nauczyciela przyczyn trudności dziecka oraz, co nie mniej ważne, poszukiwanie możliwych rozwiązań ${ }^{66}$. Konsultacje tego typu mogą służyć nie tylko diagnozowaniu problemów dziecka, ale także szukaniu możliwości wspomagania jego rozwoju, zdolności czy umiejętności. Z kolei wizyty domowe są uznawane za dobry sposób na lepsze poznanie warunków oraz środowiska, w jakich żyje uczeń. Obecnie jest to jednak dość rzadko spotykana forma współpracy ze względu na dużą wrażliwość na ochronę swojej prywatności; nauczyciel raczej niechętnie byłby widziany w progach czyjegoś domu ${ }^{67}$.

Kontakty korespondencyjne obejmują przede wszystkim dzienniczek ucznia lub zeszyt przedmiotowy, ewentualnie pisemną relację o wynikach w zachowaniu i nauce dziecka. Natomiast listy skierowane bezpośrednio do rodziców są współcześnie coraz rzadziej stosowaną formą kontaktów nauczyciela z rodzicami. Zazwyczaj dochodzi do niej, gdy zawiodły inne próby nawiązania kontaktu lub gdy jest to niemożliwe z przyczyn obiektywnych. W wielu przypadkach taka forma kontaktu staje się jedną z niewielu możliwości, szczególnie gdy inne warianty zawodzą, napotykając na przykład niechęć rodziców do bezpośredniego spotkania z nauczycielem. Współczesną wersją kontaktu tego rodzaju jest korespondencja mailowa ${ }^{68}$. Inną formą, o dużym stopniu bezpośredniości, są rozmowy telefoniczne, uznawane za jeden $z$ łatwiejszych sposobów przekazania informacji o uczniu. Współcześnie, za sprawą rozpowszechnienia telefonii komórkowej, uważa się je za jedną z najczęściej wykorzystywanych metod kontaktu. Takie rozmowy, poza zgłaszaniem nieobecności i wymiany najbardziej podstawowych informacji, mogą także służyć do budowania relacji rodzica i nauczyciela. Wynika to $\mathrm{z}$ ich indywidualnego charakteru, który pozwala na większe otwarcie obu stron ${ }^{69}$.

Wyodrębnia się sześć głównych obszarów współpracy szkoły z rodzicami. Na ich podstawie można ocenić stopień owej współpracy. Pierwszy dotyczy „komunikowania się z rodzicami”. W jego ramach ocenia się komu-

\footnotetext{
${ }^{66}$ E. Gaweł-Luty, Wymiana informacji..., s. 29.

${ }^{67}$ Tamże.

68 Tamże, s. 30.

${ }^{69}$ M. Mendel, Rodzice i nauczyciele..., s. 83.
} 
nikaty kierowane do ogółu rodziców, w większości w formie pisemnej: raporty na temat postępów uczniów, broszury, listy, ulotki. Omawiany obszar obejmuje także kontakt osobisty, w tym spotkania, wieczory rodziców itp. ${ }^{70}$

Drugi obszar współpracy został określony mianem: „Rodzice jako edukatorzy”. Tu ocenie podlega kwestia tego, czy dana szkoła uznaje edukacyjno-wychowawczą rolę rodziców. Przejawami takiego uznania są informacje przekazywane rodzicom o programie szkoły, a także stopień ich uczestnictwa w dyskusji oraz podejmowaniu wspólnych decyzji w sprawach szkolnych. Ocena dotycząca tej sfery powinna obejmować także zaangażowanie szkoły w pomoc rodzicom w doskonaleniu ich umiejętności i poszerzaniu wiedzy. Pomoc ta obejmuje m.in. organizowanie kursów, szkoleń czy pogadanek dotyczących konkretnych nurtujących rodziców tematów, na przykład uzależnień, zachowań prozdrowotnych etc.

Trzeci wyodrębniony obszar współpracy obejmuje kwestie zawierające się w haśle: „Rodzice jako pomocnicy szkoły”. W odniesieniu do wskazanej problematyki ocenie podlegają sposoby wykorzystywania przez szkołę wiedzy umiejętności rodziców w swojej pracy, a także kwestie związane z jej stosunkiem do udziału rodziców w organizowaniu zajęć pozalekcyjnych, na przykład wycieczek itp. W tym aspekcie istotną kwestią jest także wpływ szkoły na pobudzanie do aktywności rodziców dotąd mniej zaangażowanych w pomoc szkole ${ }^{71}$.

Czwarty z rozpatrywanych w omawianej koncepcji obszarów współpracy dotyczy zagadnienia, które jest określane jako: „Wsparcie dla rodziców”. Ma on na celu wsparcie rodziców przez szkołę w różnych problemach, które nie zawsze mają bezpośredni związek z edukacją, ale mogą wpłynąć na postawę rodziców wobec szkoły. W tym aspekcie najważniejsze jest to, czy szkoła potrafi zidentyfikować aktualne potrzeby społeczności rodziców i wspierać ich, albo w bezpośrednim działaniu, albo przynajmniej poprzez zgłoszenie tych problemów odpowiedniej instytucji.

Kolejny (piąty) obszar współpracy, to: „Rodzice mają głos”. W tym obszarze uwzględnia się udział rodziców w podejmowaniu konkretnych decyzji, udział w pracach rady szkoły, komitetach rodzicielskich itp.

${ }^{70}$ E. Beresford, Rola władz lokalnych we wspieraniu współpracy rodziców i szkoły, w: J. Kropiwnicki, Ku partnerstwu szkoła-rodzice, wydawnictwo nauczycielskie, Jelenia Góra 1999, s. 24.

71 E. Beresford, Rola władz lokalnych we wspieraniu współpracy rodziców i szkoły, w: J. Kropiwnicki, Ku partnerstwu szkoła - rodzice, Jelenia Góra 1999, s. 24. 
Z kolei ostatni - szósty obszar wyróżniony w omawianej koncepcji: „Szkoła i społeczność lokalna”, bada stopień korzystania przez szkołę ze wsparcia społeczności lokalnej. W tym ujęciu rodzice pełnią rolę łącznika pomiędzy szkołą a środowiskiem lokalnym. Sposobami na uzyskanie wsparcia ze strony środowiska lokalnego są m.in. organizowane przez szkołą dni otwarte (pozyskiwanie pieniędzy, wystawy prac uczniów), angażowanie wolontariuszy itp. ${ }^{72}$ Wymieniony ostatni obszar współpracy można powiązać z teorią określaną mianem pedagogiki miejsca, rozumianej jako perspektywa teoretyczna badań nad edukacją, która główny nacisk kładzie na relację człowiek - przestrzeń/miejsce. Zgodnie z jej założeniami wskazana relacja jest niezwykle istotna dla procesów uczenia się i rozwoju oraz dla tworzenia się tożsamości ludzkich, relacji społecznych i kapitału społecznego, a także wspólnot i ruchów społecznych. Ze względu na tematykę podejmowaną w niniejszym artykule szczególną uwagę należy skupić na wychowującej roli miejsca, które na różne sposoby może warunkować procesy, jakie się w nim dokonują, bezpośrednio wpływając na udział w procesie „formowania” wychowanka ${ }^{73}$.

Niezależnie od formy kontaktu czy obszaru współpracy pomiędzy rodzicami a szkołą, za jeden z najważniejszych i podstawowych wymogów efektywnej współpracy należy niewątpliwie uznać prawidłową komunikację. Brak prowadzonej właściwie komunikacji sprzyja powstaniu, a z czasem narastaniu różnych problemów na styku szkoła - rodzice ${ }^{74}$. W tym kontekście należy w szczególności uwzględnić fakt, że rodzice, jeśli interesują się szkołą, to w pierwszej kolejności przez pryzmat sytuacji ich dziecka. Dlatego jeśli szkoła myśli poważniej o nawiązaniu faktycznej współpracy z rodzicami swoich uczniów, musi zacząć przede wszystkim od udzielania informacji o nich oraz od takich form aktywności, które w bezpośredni sposób dotyczą dzieci, a nie na przykład ogólnej sytuacji placówki. Badania dotyczące tej kwestii potwierdzają, że im więcej informacji czy inicjowanych działań dotyczy ich dziecka, tym bardziej rodzic angażuje się w jego edukację. Na tej podstawie badacze tych zagadnień postulują powrót do już

\footnotetext{
72 Tamże, s. 23-29.

${ }^{73}$ Por. I. Copik, Pedagogika miejsca - kultura lokalna a kształtowanie się tożsamości wspótczesnego człowieka, „Prace Naukowe Akademii im. Jana Długosza w Częstochowie. Pedagogika”, 2013, t. XXII, s. 183.

${ }^{74}$ Por. B. Hurst, G. Reding, Profesjonalizm w uczeniu. Jak osiagnać sukces, Warszawa 2011, s. 90.
} 
nieco zapomnianych form współpracy: obserwacji lekcji przez rodziców czy ich zaangażowania $\mathrm{w}$ domowe rozwiązywanie problemów z dzieckiem, jakie mają $\mathrm{z}$ nim nauczyciele $\mathrm{w}$ trakcie lekcji itp. ${ }^{75} \mathrm{Ta}$ forma współpracy, a ściślej wsparcia przez rodziców procesu edukacyjnego w domu (np. pomoc w rozwiązywaniu zadań domowych, pozytywna postawa w stosunku do nauczyciela i szkoły), jest w rzeczywistości jedną z najczęściej praktykowanych postaci współpracy obu tych podmiotów.

Analizując zagadnienie różnych form współpracy między szkołą a rodzicami, nie można w dobie rozwoju nowych technologii zapominać o związanych z nimi możliwościach: e-mailu, dziennikach elektronicznych, wideokonferencjach, chatach itp., które tworzą nowe płaszczyzny współpracy ${ }^{76}$. Uwzględnienie aspektu miejsca, w którym odbywa się współpraca, pozwala podzielić formy współpracy na dwie główne kategorie: zaangażowanie w pracę szkoły odbywające się w placówce edukacyjnej (School Involvement) i zaangażowanie w pracę szkoły poprzez wsparcie dziecka w domu (Home Involvement $)^{77}$.

Podsumowując dotychczasowe rozważania, należy podkreślić, iż konieczność współdziałania szkoły z rodzicami i - szerzej - środowiskiem lokalnym wynika $\mathrm{z}$ braku możliwości pełnej kontroli i wychowania ucznia (dziecka) wyłącznie przez jeden podmiot ${ }^{78}$. Niewątpliwie po wprowadzeniu reformy systemu oświatowego w 1999 roku, w sferze formalno-prawnej status rodziców w szkole uległ wyraźnemu wzmocnieniu. Rodzice w świetle nowych regulacji mają większe niż dotychczas prawa do współdecydowania o programie nauczania i ogólnie wzrosła ich rola w procesie edukacji. Ocena nowych regulacji dotyczących analizowanej w pracy problematyki nie jest jednak jednoznaczna. Część teoretyków i praktyków zajmujących się kwestią roli rodziców w polskim systemie oświatowym zwraca uwagę, że wielość przyjętych w tej sferze zapisów, często poprzez swoją nieprecyzyjność czy ogólnikowość, raczej ogranicza, a nie wzmacnia ich aktyw-

\footnotetext{
${ }^{75}$ B. Śliwerski, Możliwości rozpoznawania sensu współdziałania szkoły, rodziców i uczniów w społeczeństwie wolnorynkowym, w: I. Nowosad, M. Szymański, Nauczyciele i rodzice. W poszukiwaniu nowych znaczeń i interpretacji wspólpracy, Zielona Góra-Kraków 2004, s. 52-53.

${ }^{76}$ M. Banasiak, Wspótpraca rodziców ze szkołą..., s. 41.

77 Tamże.

${ }^{78}$ Ł. Reczek-Zymróz, Współdziałanie pedagogiczne szkoły podstawowej ze środowiskiem lokalnym, Kraków 2009.
} 
ność w szkole ${ }^{79}$. Zasadne wydaje się więc pytanie o to, na ile te dążenia do włączenia rodziców w procesy edukacyjne, uczynienia z nich partnerów współpracujących ze szkołą i współodpowiedzialnych za realizowane przez nią zadania, przede wszystkim na gruncie prawa, skutkuje ich rzeczywistym uczestnictwem w życiu szkoły. Przedstawiony materiał, który należy traktować jako zaledwie przyczynek do szerszej dyskusji, dowodzi, że odpowiedź na tak postawione pytanie, o ile odnosi się do całości polskiego sytemu oświaty, powinna być negatywna. Droga do uczynienia z polskich rodziców w pełni aktywnych partnerów współczesnej polskiej szkoły jest jeszcze dość daleka.

\section{Bibliografia}

Banasiak M., Współpraca rodziców ze szkoła w kontekście reformy edukacji $w$ Polsce, Torun 2013.

Beresford E., Rola władz lokalnych we wspieraniu współpracy rodziców i szkoły, w: J. Kropiwnicki, Ku partnerstwu szkoła-rodzice, Jelenia Góra 1999.

Copik I., Pedagogika miejsca - kultura lokalna a kształtowanie się tożsamości współczesnego człowieka, „Prace Naukowe Akademii im. Jana Długosza w Częstochowie. Pedagogika”, (2013), t. XXII.

Domalewski J., Mickiewicz P., Młodzież w zreformowanym systemie szkolnym, Toruń-Warszawa 2004.

Gaweł-Luty E., Optymalizacja współdziałania nauczycieli klas początkowych z rodzicami uczniów, Słupsk 1992.

Gaweł-Luty E., Wymiana informacji pomiędzy nauczycielem-wychowawca klasy I-III szkoły podstawowej a rodzicami uczniów, Słupsk 1995.

Hurst B., Reding G., Profesjonalizm w uczeniu. Jak osiągnąć sukces, Warszawa 2011.

Koper A., Kierzkowska-Żuk I., Udział rodziców w życiu szkoły, „Studia i Prace Pedagogiczne. Rozprawy i Materiały" (2016, nr 3.

${ }^{79}$ E. Wieczorek, Prawa rodziców w polskim systemie oświatowym, w: Prawa rodziców w szkole, red. W. Starzyński i in., Warszawa 2005, s. 35. 
Kowalczyk-Szymańska M., Rodzice w zreformowanej szkole, „Nowe w Szkole" (2005), nr 3.

Łobocki M., Formy współdziałania z rodzicami, w: M. Łobocki, ABC wychowania dla nauczycieli i wychowawców, Warszawa 1992.

Łobocki M., Współdziałanie rodziców i nauczycieli w procesie wychowania, Warszawa 1985.

Mendel M., Edukacja społeczna. Partnerstwo rodziny, szkoły i gminy w perspektywie amerykańskiej, Toruń 2001.

Mendel M., Rodzice i nauczyciele jako sprzymierzeńcy, Gdańsk 2007.

Osewska E., Edukacja religijna w szkole katolickiej w Anglii $i$ Walii w świetle Living and sharing our Faith. A national Project of catechesis and religious education, Tarnów 2008.

Osewska E., Polska rodzina jako środowisko wychowania religijnego, w: Rodzina $w$ trosce o życie - Kościół $w$ trosce o rodzinę, red. R. Buchta, Studia i Materiały Wydziału Teologicznego Uniwersytetu Śląskiego w Katowicach, nr 56, Katowice 2010.

Osewska E., Praktyka katechezy rodzinnej na świecie, „Seminare”, nr 15 (1999).

Osewska E., Wspólnota rodzinna w służbie wychowania, „Family Forum” (2014), nr 4.

Parlak M., Współpraca przedszkola z rodzicami i środowiskiem lokalnym, w: E. Zyzik (red.), Wybrane zagadnienia z pedagogiki przedszkolnej, Kielce 2009.

Reczek-Zymróz Ł., Współdziałanie pedagogiczne szkoły podstawowej ze środowiskiem lokalnym, Kraków 2009.

Rodzice sa partnerami szkoły lub placówki; http://npseo.wzks.uj.edu.pl/action/requirements/wymaganie9_rodzice_sa_partnerami_szkoly (dostęp: 27.07.2018).

Rogala S., Partnerstwo rodziców i nauczycieli, Warszawa - Wrocław 1989.

Rostowska T., Wychowawcza rola szkoły w perspektywie psychologicznej, w: Wokół wychowania: rola rodziny i szkoły $w$ procesie socjalizacji dziecka, red. T. Rostowska i in., Łódź 2006.

Śliwerski B., Możliwości rozpoznawania sensu współdziałania szkoły, rodziców i uczniów w społeczeństwie wolnorynkowym, w: I. Nowosad, M. Szymański, Nauczyciele i rodzice. W poszukiwaniu nowych znaczeń i interpretacji współpracy, Zielona Góra-Kraków 2004. 
Wieczorek E., Prawa rodziców w polskim systemie oświatowym, w: Prawa rodziców w szkole, red. W. Starzyński i in., Warszawa 2005.

\section{Akty Prawne}

Ministerstwo Edukacji Narodowej do dyrektorów szkół, MEN, Warszawa 1999.

Ministerstwo Edukacji Narodowej o dysleksji, czyli specyficznych trudnościach w nauce, MEN, Warszawa 1999.

Ministerstwo Edukacji Narodowej o ocenianiu, MEN, Warszawa 1999.

Ministerstwo Edukacji Narodowej o programach nauczania, gimnazjum, MEN, Warszawa 1999.

Ministerstwo Edukacji Narodowej o programie wychowawczym szkoły, MEN, Warszawa 2001.

Ministerstwo Edukacji Narodowej o programie wychowawczym szkoły, MEN, Warszawa 2001.

Ministerstwo Edukacji Narodowej o reformie programowej, kształcenie zintegrowane, MEN, Warszawa 1999.

Ministerstwo Edukacji Narodowej o wychowaniu w szkole, MEN, Warszawa, 1999.

Rozporządzenie Ministra Edukacji Narodowej z dnia 6 sierpnia 2015 r. w sprawie wymagań wobec szkół i placówek (Dz.U. 2015 poz. 1214).

Ustawa z dnia 11 kwietnia 2007 r. o zmianie ustawy o systemie oświaty oraz o zmianie niektórych innych ustaw (Dz.U. z 2007r. Nr 80, poz. 542).

Ustawa z dnia 14 grudnia 2016 r. Prawo oświatowe, art. 84 (Dz.U. z 2018 r. poz. 996, 1000 i 1290).

Ustawa z dnia 25 lipca 1998 r. o zmianie ustawy o systemie oświaty (Dz.U. 1998, nr 117, poz.759; nr 162, poz. 1126.).

Ustawa z dnia 25 lipca 2008 r. o zmianie ustawy o systemie oświaty, Ustawy - Karta Nauczyciela oraz Ustawy o postępowaniu w sprawach nieletnich (Dz.U. z dnia 8 sierpnia 2008 r.).

Ustawa z dnia 26 stycznia 1982 r. Karta Nauczyciela z późniejszymi zmianami.

Ustawa z dnia 5 listopada 2009 r. zmieniająca ustawę o systemie oświaty oraz ustawę o zmianie ustawy o systemie oświaty oraz o zmianie niektórych innych ustaw (Dz.U. z dnia 22 grudnia 2009 r.). 
Ustawa z dnia 7 września 1991 r. o systemie oświaty (tekst jednolity: Dz.U. z 1996 r. Nr 67, poz. 329, z późn. zm.).

Ustawa z dnia 7 września 1991 r. o systemie oświaty i jej nowelizacja z dnia 11 kwietnia $2007 \mathrm{r}$.

Załącznik do Rozporządzenia Ministra Edukacji Narodowej i Sportu z dnia 23 kwietnia 2004 r. w sprawie szczegółowych zasad sprawowania nadzoru pedagogicznego, wykazu stanowisk wymagających kwalifikacji pedagogicznych, kwalifikacji niezbędnych do sprawowania nadzoru pedagogicznego, a także kwalifikacji osób, którym można zlecać prowadzenie badań i opracowywanie ekspertyz (Dz.U. 2004 nr 89, poz. 845).

Załącznik do Rozporządzenia Ministra Edukacji Narodowej i Sportu z dnia 23 kwietnia 2004 r. (Dz.U. 2004 nr 89, poz. 845).

Załącznik do Rozporządzenia Ministra Edukacji Narodowej z dnia 7 października 2009 r. w sprawie nadzoru pedagogicznego (Dz.U. $2009 \mathrm{nr}$ 168 poz. 1324 , z późn. zm.).

Zarządzenie Ministra Edukacji Narodowej z dnia 8 kwietnia 1997 roku w sprawie zadań nauczycieli, którym powierzono stanowiska kierownicze w szkole. 
Aniwersytet Papieski

Tf: Ja! Jana Pawła II

(ii w Krakowie 